\title{
Drug-induced dyskinesias, can they be prevented?
}

\author{
Dyskinezy polekowe, czy można im zapobiec?
}

\section{Małgorzata Romaniuk ${ }^{1}$ ABCDEF, https://orcid.org/0000-0001-8838-6291, Konrad Suswał ${ }^{1}$ ABCDE, Aleksandra Skałecka ${ }^{1}$ ABCE, Maria Gromek ${ }^{1}$ BCDE, Martyna Kozłowska ${ }^{1}$ CEF, Paweł Krukow² DEF, https://orcid.org/0000-0001-9497-2713}
${ }^{1}$ Psychiatry Student Research Group I Department of Psychiatry, Psychotherapy and Early Intervention, Medical University of Lublin
${ }^{2}$ Department of Clinical Neuropsychiatry, Medical University of Lublin

\begin{abstract}
Introduction: Dyskinesia is a symptom complex in the form of involuntary, repetitive movements of lips, lower jaw, tongue, less often the trunk and limbs. Despite the use of newer drugs in treatment neuroleptics, dyskinesia has not ceased to be a clinical problem.

Method: The work is based on a research review for which the Google Scholar database was used as well PubMed. The search range was limited to 2008-2020. We have included descriptive publications tardive dyskinesia only as a consequence of antipsychotic medications.

Material: We present the use of tetrabenazine analogues, deep brain stimulation, neuroleptics, benzodiazepines and botulinum toxin in late-suffering patients drug-induced dyskinesias, which may indicate an improvement in your health.

Discussion: The first method of treating tardive dyskinesia are withdrawal antipsychotic medications, but for many patients this is impossible. Valbenazine and Deep Brain Stimulation are the most effective in treating Tardive Dyskinesia.

Conclusions: There are not enough studies with the highest reliability to create unequivocal recommendations in the treatment of drug-induced tardive dyskinesia.
\end{abstract}

Keywords: drug-induced dyskinesias, neuroleptics, dystonia

\section{Streszczenie}

Wstęp: Dyskinezy to zespół objawów pod postacią mimowolnych, powtarzających się ruchów warg, żuchwy, języka, rzadziej tułowia i kończyn. Mimo stosowania w leczeniu nowszych leków neuroleptycznych, dyskinezy nie przestały być problemem klinicznym.

Metoda: Praca opiera się na przeglądzie badań, do których wykorzystano bazę Google Scholar oraz PubMed. Zasięg poszukiwań ograniczono do lat 2008-2020. Uwzględniliśmy publikacje opisujące późne dyskinezy polekowe tylko w następstwie stosowania leków przeciwpsychotycznych.

Materiał: Prezentujemy zastosowanie analogów tetrabenazyny, głębokiej stymulacji mózgu, neuroleptyków, benzodiazepin oraz toksyny botulinowej u pacjentów cierpiących na późne dyskinezy polekowe, które mogą wskazywać na poprawę stanu zdrowotnego.

Dyskusja: Pierwszą metodą leczenia późnych dyskinez jest odstawienie leków przeciwpsychotycznych, jednak w przypadku wielu pacjentów jest to niemożliwe. Największą skuteczność w leczeniu ma walbenazyna oraz głęboka stymulacja mózgu.

Wnioski: Brakuje wystarczającej liczby badań o najwyższej wiarygodności, aby stworzyć jednoznaczne rekomendacje w leczeniu późnych dyskinez polekowych.

Słowa kluczowe: dyskinezy polekowe, leki neuroleptyczne, dystonia

\section{Introduction}

The use of antipsychotics can cause many side effects. As a result of chronic use of neuroleptics, usually for many years, increased expression of dopaminergic receptors and their hypersensitization occurs, which continues thrust causing an increase in dopamine neurotransmission in the 
basal ganglia. It works the appearance of side effects in the form of drug-induced dyskinesias.

Dyskinesias is a group of symptoms in the form of involuntary, repeated movements of the lips, the jaw, tongue, less often the torso and limbs, e.g. kissing, licking, chewing movements concerning the mouth, tongue and lower jaw. The risk of their manifestation increases in intermittent high-dose treatments daily use of neuroleptic drugs or when they are suddenly stopped. Dyskinesia subsides in only $5-40 \%$ of cases and may persist for a long time, up to 5 years after discontinuation the drug causing them. Reduction of the dose of the drug or changing to an atypical neuroleptic with a lower potential of inducing dyskinesia is recommended in the first place in therapeutic treatment $[1,2]$.

Despite the use of newer neuroleptic drugs in the treatment, dyskinesias have not stopped being a clinical problem. Establishing treatment therapy (TD, org. Tardive dyskinesia) can be problematic as few advised drugs have been clinically tested to the appropriate level enabling recommendation [3]. The incidence of dyskinesias in 32\% of cases results from the use of typical neuroleptics, and in $13 \%$ of atypical neuroleptics, recommended for therapy in the event of dyskinesias. TD occurs most often after at least 1 year of continuous exposure to dopamine blocking agents, especially first-generation antipsychotics, however, it can be seen among patients after 3 months of therapy [4].

The aim of the study is to present a literature review regarding evidence of effective action of selected substances and non-pharmacological methods of TD therapy. We present the use of tetrabenazine analogs, deep brain stimulation, neuroleptics, benzodiazepines and toxins botulinum toxin in patients suffering from drug-induced tardive dyskinesia that may be indicative of improving your health.

\section{Method}

The work is based on a research review, for which the Google Scholar database was used and PubMed, which has a wide range of topics for managing acute drug-induced dyskinesias (TD). The search range was limited to 20082020. Key words were tardive dyskinesia, neuroleptics, dystonia. We have included publications describing TD only as a consequence of antipsychotic medications.

\section{Material}

\section{Dyskinesia and neuroleptics}

The incidence of drug-induced dyskinesias in the first year of using antipsychotic drugs is estimated at $5 \%$, while in subsequent years it increases even up to $50 \%$ [5]. Firstgeneration antipsychotics have the greatest potential to cause dyskinesias. The published reports show that in the case of typical neuroleptics, the incidence of TD is 32\%, whereas for atypical neuroleptics this frequency drops to $13 \%$. Lower risk of TD due to new-generation neuroleptics may result from their pharmacokinetics - these drugs are relatively weaker at blocking D2 receptors and quickly (12-24 hours after a single dose) detach from dopamine receptors, unlike the first generation neuroleptics, which bond stronger and remain longer attached to D2 receptors [6]. Regardless of the differences, TD remains essential problem potentially associated with all antipsychotics [7].

The use of new generation neuroleptics in antipsychotic treatment reduces the risk of tardive dyskinesia. Among them, clozapine and quetiapine have the weakest binding strength to D2 receptors and thus the lowest potential for inducing TD. For this reason, if possible, it is recommended to replace a typical neuroleptic with an atypical one in therapeutic management [3]. However, it should be remembered that atypical neuroleptics can also cause tardive dyskinesia, for example: atypical risperidone in $6 \mathrm{mg}$ doses a day increases the risk of TD. Complete or abrupt withdrawal of drugs has also not been proven as effective in treating TD, and may even aggravate symptoms.

In their article, Haile and Umer described the case of a patient suffering from catatonic schizophrenia, who after 8 years of taking chlorpromazine in a dose of $200 \mathrm{mg}$ / day developed abnormal, involuntary body movements. Doctors tried to discontinue the current treatment and introduced the following drugs gradually: olanzapine, clozapine and clonazepam. This was the use of clozapine at a dose of $500 \mathrm{mg} /$ day and clonazepam at a dose of 4 mg / day that gave a noticeable improvement, and the dyskinetic movements almost completely disappeared [8].

\section{Tetrabenazine analogs}

The VMAT2 inhibitors deutetrabenazine and valbenazine currently have the most rigorous evidence of treatment efficacy and safety in the TD population. While antipsychotics can also mask the symptoms of TD, VMAT2 inhibitors have the advantage over drugs from this group that they do not seem to cause troublesome neurological side effects, nor do they cause tardive dyskinesia themselves. Follow-up studies provided new evidence on the subject of the efficacy and tolerability of two tetrabenazine analogs -- valbenazine and deutetrabenazine. The mechanism of action of these drugs is based on the reduction of dopamine levels, thereby reducing the severity of TD and inhibiting the vesicular monoamine transporter-2 (VMAT-2). Valbenzine and deutetrabenazine have a longer half-life, and are therefore metabolized more slowly in the body. Rigorous trials have confirmed that both drugs are more effective than placebo 
in reducing the severity of TD and are better tolerated than tetrabenazine [9]. Caroff in his study showed that the use of valbenazine reduces the symptoms of TD, even 4 weeks after its discontinuation [10].

\section{Deep brain stimulation}

Deep brain stimulation (DBS) is used in the treatment of mental diseases, especially in pharmacotherapyresistant cases. Another example of the use of deep brain stimulation is drug-induced tardive dyskinesias treatment. DBS modulates the pathological oscillatory activity between brain regions. The mechanism is based on the local action of the electrode on the neuronal activity, which is transmitted to monosynchronous and polisynaptic connections.

Macerollo and Deuschl have shown that the treatment of tardive dyskinesia brain stimulation in the region of the internal globus pallidus (GPi-DBS org. internal globus pallidus deep brain stimulation) or the hypothalamic nucleus (STN-DBS, org. subthalamic nucleus deep brain stimulation) may be considered in patients with severe drug-resistant symptoms. Single case reports suggest a favorable and relatively safe action of DBS. However, the authors emphasize that more precise data are needed that can only be obtained from randomized controlled clinical trials with double-blind on an appropriate representative group [11].

Zheng DaoDeng et al. conducted their research on 10 patients with refractory TD. The average follow-up time was 12-105 months. There was an improvement in motor function noticeable on the Burke-Fahn-Marsden Dystonia Rating Scale (BFMDRS) and Abnormal Involuntary Movement Scale (AIMS) by $87.3 \%$ and $88.4 \%$ respectively. This result persisted in long-term observation. The research shows that DBS orientated towards the hypothalamus nucleus can be an effective and acceptable procedure for $\mathrm{TD}$, leading to a permanent significant improvement in both movement and psychiatric symptoms [12].

\section{Dyskinesias and benzodiazepines}

Based on the American Academy of Neurology (AAN) therapeutic classification scheme, clonazepam is likely to be effective in the treatment of TD [13]. GABAergic drugs are believed to provide short-term improvement in TD symptoms, but also have significant side effects and are unlikely to be effective in the long term. The authors report that in patients with bothersome symptoms of TD, despite using the lowest effective dose of DRBA, treatment with valbenaazine or deutetrabenazine (or tetrabenazine if newer VMAT2 inhibitors are unavailable) is recommended first.

There is a reported case of a patient with TD induced with aripiprazole, which proves the therapeutic effect of clozapine. Clozapine was used in combination therapy with tetrabenazine and botulinum toxin [14]. Even though the drug has some restrictions (risk of agranulocytosis), it may be an effective alternative in the treatment of drugresistant TD.

Bergman et al. analyzed the effects of benzodiazepines on antipsychotic-induced tardive dyskinesia among people with schizophrenia, schizoaffective disorder, or other chronic mental illness. They obtained inconclusive results showing that routine clinical use of benzodiazepines is not advisable, and that these therapies still remain experimental [15].

\section{Dyskinesias and botulinum toxin}

Botulinum toxin inhibits the secretion of acetylcholine, binding with presynaptic nerve endings [16]. It works by weakening the muscles involved in triggering the tic. Botulinum toxin seems to be a better option (despite insufficient research) in the treatment of focal drug-induced dystonia, such as cervical dystonia or blepharospasm [3]. The most significant risk associated with botulinum toxin therapy is severe dysphagia. Considering the risks, the treatment is relatively safe with a negligible amount of side effects.

Aguilar et al. reported an aripiprazole-induced TD case in which botulinum toxin was used in combination with clozapine and tetrabensin. After the therapy was started, the patient's health improved significantly, and the dyskinetic symptoms were minimized [14]. The authors suggest that this combination of drugs, which has not been used before, may be of benefit to TD patients.

Slotema et al. conducted a study on a group of $12 \mathrm{TD}$ patients who received botulinum toxin A therapy. The substance was administered in three sessions and with increasing doses. An insignificant relief of TD symptoms was observed, however, in patients who remained on stable doses of neuroleptics, the reduction of TD symptoms was significant. The intensification of symptoms was measured by Abnormal Involuntary Movement (AIMS). The authors of the study claim that it is necessary to carry out a double blind test [17].

\section{Discussion}

Tardive dyskinesia prevention begins with the prescription of antipsychotic drugs, the physician should discuss the risk of movement disorders with the patient and use the lowest possible dose of the drug least associated with TD [18]. Withdrawal of antipsychotics is the first treatment option, but this is not possible for many patients. Does drug dose reduction minimise TD symptoms?

Valbenazine and DBS seem to be the most effective 
in treating $\mathrm{TD}$, reducing symptoms and being relatively safe. Neuroleptic drugs, according to the 2013 Evidencebased guideline recommendations, are not advised for the treatment of dyskinesias, and in some cases they may aggravate the symptoms of TD [13]. The use of clonazepam in TD gives a statistically significant improvement in both dyskinesia and dystonia, but it has a strong addictive potential, and the therapy remains experimental. Positive results with botulinum toxin should be interpreted with caution, regarding the lack of large studies using doubleblind, control groups or standard therapy parameters. The amount of evidence that botulinum toxin is effective is considered insufficient [19].

Prevention remains the best strategy to treat TD. Screening tests and the frequency of their taking, the doses and duration of using the drug play a key role in the early diagnosis and thus the prevention of TD [10].

\section{Conclusions}

1. Tetrabenazine may be an effective therapeutic option for the treatment of TD. In cases of complex and very intense movements, treatment with DBS should be considered [3].

2. In the presented publications, good results of TD treatment were not obtained, which shows that it is a continuous problem in medical practice.

3. It is necessary to conduct further scientific studies on larger groups of patients, which would help to develop guidelines for the treatment of TD.

\section{Wstęp}

Stosowanie leków przeciwpsychotycznych może powodować wiele działań niepożądanych. Wskutek przewlekłego, najczęściej wieloletniego, stosowania neuroleptyków dochodzi do zwiększonej ekspresji receptorów dopaminergicznych oraz ich hipersensytyzacji, co w dalszym ciągu powoduje wzrost neurotransmisji dopaminy w zwojach podstawy mózgu. Skutkuje to pojawieniem się objawów niepożądanych pod postacią dyskinez polekowych.

Dyskinezy to zespół objawów pod postacią mimowolnych, powtarzających się ruchów warg, żuchwy, języka, rzadziej tułowia i kończyn, np. ruchy cmokania, lizania, żucia dotyczące ust, języka i żuchwy. Ryzyko ich ujawnienia zwiększa się $\mathrm{w}$ przerywanych kuracjach dużymi dawkami dobowymi leków neuroleptycznych lub przy nagłym ich odstawieniu. Dyskinezy ustępują w zaledwie 5-40\% przypadków i mogą się utrzymywać długotrwale, nawet do 5 lat po odstawieniu wywołującego je leku. W pierwszej kolejności w postępowaniu leczniczym zaleca się redukcję dawki stosowanego leku lub zmianę na neuroleptyk atypowy o niższym potencjale wywoływania dyskinez $[1,2]$.

Mimo stosowania w leczeniu nowszych leków neuroleptycznych, dyskinezy nie przestały być problemem klinicznym. Ustalenie terapii leczenia (TD, org. Tardive Dyskinesia, późne dyskinezy) może stwarzać problemy, gdyż niewiele zalecanych leków przeszło badania kliniczne na odpowiednim poziomie umożliwiającym rekomendację [3]. Częstość występowania dyskinez polekowych w 32\% przypadków jest skutkiem stosowania typowych neuroleptyków, a w 13\% neuroleptyków atypowych, zalecanych w terapii w przypadku wystąpienia dyskinez. TD występuje najczęściej po co najmniej 1 roku nieprzerwanej ekspozycji na środki blokujące receptory dopaminy, zwłaszcza leki przeciwpsychotyczne pierwszej generacji, jednakże można to zauważyć u pacjentów już po
3 miesiącach terapii [4].

Celem pracy jest przedstawienie przeglądu literatury dotyczącego dowodów na skuteczne działanie wybranych substancji i niefarmakologicznych metod terapii TD. Prezentujemy zastosowanie analogów tetrabenazyny, głębokiej stymulacji mózgu, neuroleptyków, benzodiazepin oraz toksyny botulinowej u pacjentów cierpiących na późne dyskinezy polekowe, które mogą wskazywać na poprawę stanu zdrowotnego.

\section{Metoda}

Praca opiera się na przeglądzie badań, do których wykorzystano bazę Google Scholar oraz PubMed, która ma szeroki zakres tematyczny odnośnie postępowania w ostrych dyskinezach polekowych (TD). Zasięg poszukiwań ograniczono do lat 2008-2020. Słowa klucz, które zostały zastosowane to tardive dyskinesia, neuroleptics, dystonia. Uwzględniliśmy publikacje opisujące TD tylko w następstwie stosowania leków przeciwpsychotycznych.

\section{Materiał}

\section{Dyskinezy, a neuroleptyki}

Występowanie dyskinez polekowych w ciągu pierwszego roku stosowania leków przeciwpsychotycznych szacuje się na poziomie 5\%, natomiast $\mathrm{w}$ kolejnych latach wzrasta ono nawet do 50\% [5]. Największy potencjał wywoływania dyskinez mają leki przeciwpsychotyczne pierwszej generacji. Z opublikowanych raportów wynika, że w przypadku typowych neuroleptyków częstość występowania TD wynosi 32\%, dla atypowych neuroleptyków częstość ta spada już do 13\%. Mniejsze ryzyko wystąpienia TD w przypadku neuroleptyków nowej generacji może wynikać z ich farmakokinetyki - leki te stosunkowo 
słabiej blokują receptory D2 i szybko (12-24h po podaniu pojedynczej dawki) odłączają się od receptorów dopaminowych, w przeciwieństwie do neuroleptyków pierwszej generacji, które posiadają silniejsze wiązanie i pozostają dłużej połączone z receptorami D2 [6]. Niezależnie od różnic TD pozostaje istotnym problemem potencjalnie związanym ze wszystkimi lekami przeciwpsychotycznymi [7].

Zastosowanie w leczeniu przeciwpsychotycznym neuroleptyków nowej generacji zmniejsza ryzyko rozwinięcia późnych dyskinez. Wsród nich klozapina i kwetiapina mają najsłabszą siłę wiązania z receptorami D2, a przez to najmniejszy potencjał wywoływania TD. $\mathrm{Z}$ tego powodu, jeżeli istnieje u pacjenta taka możliwość, to $\mathrm{w}$ postępowaniu terapeutycznym zaleca się zamianę neuroleptyku typowego na atypowy [3]. Należy jednak pamiętać, że neuroleptyki atypowe również mogą powodować dyskinezy późne - dla przykładu: atypowy risperidon, w niestandardowych dawkach $6 \mathrm{mg} /$ dobę zwiększa ryzyko TD. Całkowite lub nagłe odstawienie leków również nie ma potwierdzonej skuteczności w zwalczaniu TD, a wręcz może nasilić objawy.

W swoim artykule Haile i Umer opisali przypadek pacjenta cierpiącego na schizofrenię katatoniczną, który po 8 latach przyjmowania chlorpromazyny w dawce $200 \mathrm{mg} /$ dobę rozwinął nieprawidłowe, mimowolne ruchy ciała. Lekarze podjęli próbę odstawienia dotychczasowego leczenia i włączenia stopniowo następujących leków: olanzapiny, klozapiny oraz klonazepamu. To właśnie zastosowanie klozapiny $\mathrm{w}$ dawce $500 \mathrm{mg} /$ dobę oraz klonazepamu w dawce $4 \mathrm{mg} /$ dobę dało zauważalną poprawę, a ruchy dyskinetyczne prawie całkowicie zniknęły [8].

\section{Analogi tetrabenazyny}

Inhibitory VMAT2, deutetrabenazyna i walbenazyna, mają obecnie najbardziej rygorystyczne dowody skuteczności leczenia i bezpieczeństwa w populacji TD. Chociaż leki przeciwpsychotyczne mogą również maskować objawy TD, inhibitory VMAT2 mają tę przewagę nad lekami z tej grupy, że nie wydają się powodować uciążliwych neurologicznych skutków ubocznych ostrych reakcji dystonicznych lub same wywoływać późne dyskinezy.

Badania kontrolne dostarczyły nowych dowodów na temat skuteczności i tolerancji dwóch analogów tetrabenazyny - walbenazyny i deutetrabenazyny. Mechanizm działania tych leków polega na obniżeniu poziomu dopaminy, tym samym zmniejszając nasilenie TD oraz hamując pęcherzykowy transporter monoaminowy-2 (VMAT-2). Walbenzyna i deutetrabenazyna mają dłuższy okres półtrwania, przez co są wolniej metabolizowane w organizmie. Rygorystyczne próby potwierdziły, że oba leki są bardziej skuteczne niż placebo w zmniejszaniu nasilenia TD i są lepiej tolerowane niż tetrabenazyna [9]. Caroff w swoim badaniu wykazał, że stosowanie walbenazyny wpływa na zmniejszenie objawów TD, nawet 4 tygodnie po jej odstawieniu [10].

\section{Głęboka stymulacja mózgu}

Głęboka stymulacja mózgu (DBS org. Deep Brain Stimulation, głęboka stymulacja mózgu) znajduje zastosowanie $\mathrm{w}$ leczeniu chorób psychicznych zwłaszcza w przypadkach opornych na farmakoterapię. Innym przykładem zastosowania głębokiej stymulacji mózgu jest terapia późnych dyskinez polekowych. DBS polega na modulacji patologicznej aktywności oscylacyjnej między regionami mózgu. Odbywa się ona poprzez miejscowe działanie elektrody na aktywność neuronalną, która jest przekazywana do monosynchronicznych i wielosynaptycznych połączeń sieciowych.

Macerollo i Deuschl wykazali, że leczenie klasycznych późnych dyskinez głęboką stymulacją mózgu w obszarze gałki bladej wewnętrznej (Gpi-DBS org. internal globus pallidus deep brain stimulation) lub jądra podwzgórza (STN-DBS, org. subthalamic nucleus deep brain stimulation) można rozważyć u pacjentów z ciężkimi objawami, opornymi na leki. Raporty z pojedynczych przypadków sugerują korzystne i stosunkowo bezpieczne działanie DBS. Autorzy podkreślają, że potrzebne są jednak dokładniejsze dane, które można uzyskać tylko dzięki randomizowanym, kontrolowanym badaniom klinicznym z podwójną ślepą próbą na odpowiedniej grupie reprezentatywnej [11].

Zheng DaoDeng i inni swoje badania przeprowadzili na 10 pacjentach $\mathrm{z}$ opornym na leczenie TD. Średni czas obserwacji wynosił 12-105 miesięcy. Poprawa w zakresie funkcji motorycznych była zauważalna w skalach dystonii Burke-Fahna-Marsdena (BFMDRS) oraz skali nieprawidłowego ruchu mimowolnego (AIMS) odpowiednio o 87,3\% i 88,4\%. Rezultat ten utrzymywał się w oberwacji długoterminowej. Z przeprowadzonych badań wynika, że DBS ukierunkowany na jądro podwzgórza może być skuteczną i akceptowalną procedurą dla TD, prowadzącą do trwałej i znaczącej poprawy zarówno w zakresie ruchu, jak i objawów psychiatrycznych [12].

\section{Dyskinezy, a benzodiazepiny}

Na podstawie schematu klasyfikacji terapeutycznej Amerykańskiej Akademii Neurologii (AAN) ustalono, że klonazepam jest prawdopodobnie skuteczny w leczeniu TD [13]. Przypuszcza się, że leki GABA-ergiczne mogą zapewnić krótkotrwałą poprawę objawów TD, ale również mieć znaczące skutki uboczne i jest mało prawdopodobne, aby były skuteczne w dłuższej perspektywie. Autorzy podają, że u pacjentów z uciążliwymi objawami TD, 
pomimo stosowania najniższej skutecznej dawki DRBA, zaleca się w pierwszej kolejności leczenie walbenazyną lub deutetrabenazyną (lub tetrabenazyną, jeśli nowsze inhibitory VMAT2 są niedostępne).

Opisano przypadek pacjentki z TD indukowanym arypiprazolem, który potwierdza skuteczność działania terapeutycznego klozapiny, zastosowanej w terapii skojarzonej wraz z tetrabenazyną i toksyną botulinową [14]. Chociaż lek ma pewne ograniczenia (ryzyko agranulocytozy), może być skuteczną alternatywą w leczeniu nieodwracalnego TD.

Bergman i inni analizowali wpływ benzodiazepin na późne dyskinezy wywołane lekami przeciwpsychotycznymi u osób ze schizofrenią, zaburzeniami schizoafektywnymi lub innymi przewlekłymi chorobami psychicznymi. Otrzymali niejednoznaczne wyniki, które pokazują, że rutynowe stosowanie kliniczne beznodiazepin nie jest wskazane, a terapie te są nadal eksperymentalne [15].

\section{Toksyna botulinowa}

Toksyna botulinowa hamuje wydzielanie acetylocholiny, która wiąże się z presynaptycznymi zakończeniami nerwowymi [16]. Działanie leku polega na osłabieniu mięśni zaangażowanych w wykonanie tiku. Toksyna botulinowa wydaje się najlepszą opcją (mimo braku specyficznych badań) w leczeniu ogniskowej dystonii polekowej, na przykład dystonii szyjnej lub kurczu powiek [3]. Najbardziej znaczącym ryzykiem związanym z terapią toksyną botulinową jest ciężka dysfagia. Biorąc pod uwagę ryzyko, leczenie jest stosunkowo bezpieczne, przy niewielkim poziomie działań niepożądanych.

Aguilar i inni opisali przypadek TD wywołanym przyjmowaniem arypiprazolu, w którym toksyna botulinowa znalazła zastosowanie w skojarzeniu z klozapiną i tetrabenzyną. Po wdrożeniu takiej terapii stan zdrowia pacjentki uległ znaczącej poprawie, a objawy dyskinetyczne zostały zminimalizowane [14]. Autorzy sugerują, że taka kombinacja leków, wcześniej nie stosowana może być korzystna u pacjentów z TD.

Slotema i inni przeprowadzili badania na grupie 12 pacjentów z TD, u których zastosowano terapię toksyną botulinową A. Substancję podawano w trzech kolejnych sesjach wraz ze zwiększającymi się dawkami. Stwierdzono nieistotne zmniejszenie nasilenia TD, jednak u pacjentów, którzy pozostawali na stałych dawkach neuroleptyków redukcja objawów TD była znacząca. Nasilenie mierzono za pomocą skali nieprawidłowego ruchu mimowolnego (AIMS). Autorzy uważają, że niezbędne jest większe badanie z podwójną ślepą próbą [17].

\section{Dyskusja}

Zapobieganie późnym dyskinezom rozpoczyna się w momencie przepisywania leków przeciwpsychotycznych, lekarz powinien omówić $\mathrm{z}$ pacjentem ryzyko wystąpienia zaburzeń ruchowych i zastosować najniższą możliwą dawkę leku najmniej związanego z TD [18]. Pierwszą metodą leczenia jest odstawienie leków przeciwpsychotycznych, jednak w przypadku wielu pacjentów jest to niemożliwe. Czy zmniejszenie dawki leków, powoduje zmniejszenie objawów TD?

Wydaje się, że największą skuteczność w leczeniu TD ma walbenazyna oraz DBS, które zmniejszają objawy oraz są stosunkowo bezpieczne. Leki neuroleptyczne według rekomendacji Evidence-based guideline z 2013 roku nie są zalecane w terapii dyskinez, a w niektórych przypadkach mogą nasilać objawy TD [13]. Zastosowanie klonazepamu w TD daje istotną statystycznie poprawę zarówno w zakresie dyskinez, jak i dystonii, jednak ma silny potencjał uzależniający, a terapia pozostaje dalej eksperymentalna. Pozytywne wyniki z toksyną botulinową należy interpretować z ostrożnością, biorąc pod uwagę brak dużych badań wykorzystujących podwójne zaślepienie, grupy kontrolne lub standardowe parametry terapii. Ilość dowodów na skuteczność toksyny botulinowej uważa się za niewystarczającą [19].

Wciąż najlepszą strategią walki z TD pozostaje profilaktyka. We wczesnym rozpoznaniu, a przez to zapobieganiu TD, kluczową rolę odgrywają badania przesiewowe, częstotliwość ich wykonywania, zastosowane dawki leku oraz czas jego przyjmowania [10].

\section{Wnisoki}

1. Tetrabenazyna może być skuteczną opcją terapeutyczną w leczeniu TD. W przypadkach złożonych i bardzo nasilonych ruchów warto rozważyć leczenie za pomocą DBS [3].

2. W przedstawionych publikacjach nie uzyskano dobrych efektów leczenia TD, co pokazuje, że jest to ciągły problem w praktyce lekarskiej.

3. Niezbędne jest przeprowadzenie kolejnych badań naukowych na większych grupach pacjentów, które pomogłyby w opracowaniu wytycznych postępowania w leczeniu TD.

\section{Conflict of interest}

The authors have declared no conflict of interest.

\section{References:}

1. Mosiołek A. Objawy pozapiramidowe w psychiatrii diagnostyka i leczenie. Psychiatria 2014;11(3):160-165.

2. Sapa J. Wybrane choroby i zaburzenia polekowe - możliwości profilaktyki i leczenia. Część I. Farm. Pol. 2009; 65 (10): 733-742.

3. Sławek J, Białecka M, Dudek D, Koziorowski D, Rudzińska-Bar M. Późne dyskinezy polekowe - rekomendacje grupy ekspertów. 
Pol. Przegl. Neurol 2017;13(3):93-105.

4. Patel RS, Mansuri Z, Motiwala F, et al. A systematic review on treatment of tardive dyskinesia with valbenazine and deutetrabenazine. Ther Adv Psychopharmacol. 2019;9:2045125319847882. doi:10.1177/2045125319847882

5. Kane JM. Tardive dyskinesia rates with atypical antipsychotics in adults: prevalence and incidence. 2004; 65, 9: 16-20.

6. Waln O, Jankovic J. An update on tardive dyskinesia: from phenomenology to treatment. Tremor Other Hyperkinet Mov (N Y). 2013;3:tre-03-161-4138-1. doi:10.7916/D88P5Z71

7. D'Abreu A, Akbar U, Friedman JH. Tardive dyskinesia: Epidemiology. J Neurol Sci. 2018;389:17-20. doi:10.1016/j. jns.2018.02.007

8. Haile $\mathrm{K}$, Umer $\mathrm{H}$. The use of clozapine and clonazepam co-administration in the treatment of a severe tardive dyskinesia: A case report. SAGE Open Med Case Rep. 2019;7:2050313X19833254. doi:10.1177/2050313X19833254

9. Caroff SN, Aggarwal S, Yonan C. Treatment of tardive dyskinesia with tetrabenazine or valbenazine: a systematic review. J Comp Eff Res. 2018;7(2):135-148. doi:10.2217/cer-2017-0065

10. Caroff SN. Overcoming barriers to effective management of tardive dyskinesia. Neuropsychiatr Dis Treat. 2019;15:785-794. doi:10.2147/NDT.S196541

11. Macerollo A, Deuschl G. Deep brain stimulation for tardive syndromes: Systematic review and meta-analysis. J Neurol Sci. 2018;389:55-60. doi:10.1016/j.jns.2018.02.013

12. Deng ZD, Li DY, Zhang CC, et al. Long-term follow-up of bilateral subthalamic deep brain stimulation for refractory tardive dystonia. Parkinsonism Relat Disord. 2017;41:58-65. doi:10.1016/j.parkreldis.2017.05.010

13. Bhidayasiri R, Jitkritsadakul O, Friedman JH, Fahn S. Updating the recommendations for treatment of tardive syndromes: A systematic review of new evidence and practical treatment algorithm. J Neurol Sci. 2018;389:67-75. doi:10.1016/j. jns.2018.02.010

14. Aguilar L, Lorenzo C, Fernández-Ovejero R, Roncero C, Montejo AL. Tardive Dyskinesia After Aripiprazole Treatment That
Improved With Tetrabenazine, Clozapine, and Botulinum Toxin. Front Pharmacol. 2019;10:281. doi:10.3389/fphar.2019.00281

15. Bergman H, Bhoopathi PS, Soares-Weiser K. Benzodiazepines for antipsychotic-induced tardive dyskinesia. Cochrane Database Syst Rev. 2018;1(1):CD000205. doi:10.1002/14651858. CD000205.pub3.

16. Chatterjee, Anjan MD; Forrest Gordon, Mark MD; Giladi, Nir MD; Trosch, Richard MD Botulinum Toxin in the Treatment of Tardive Dystonia, Journal of Clinical Psychopharmacology: December 1997 - Volume 17 - Issue 6 - p 497-498

17. Slotema CW, van Harten PN, Bruggeman R, Hoek HW. Botulinum toxin in the treatment of orofacial tardive dyskinesia: a single blind study. Prog Neuropsychopharmacol Biol Psychiatry. 2008;32(2):507-509. doi:10.1016/j.pnpbp.2007.10.004

18. Cornett EM, Novitch M, Kaye AD, Kata V, Kaye AM. MedicationInduced Tardive Dyskinesia: A Review and Update. Ochsner J. 2017;17(2):162-174.

19. Cloud LJ, Zutshi D, Factor SA. Tardive dyskinesia: therapeutic options for an increasingly common disorder. Neurotherapeutics. 2014;11(1):166-176. doi:10.1007/s13311013-0222-5.

\section{Corresponding author}

Małgorzata Romaniuk

Psychiatry Student Research Group I Department of Psychiatry, Psychotherapy and Early Intervention, Medical University of Lublin e-mail: goszarom@gmail.com

Otrzymano: 24.08.2020

Zrecenzowano:26.08.2020

Przyjęto do druku: 28.08.2020 